КОМАРНИЦЬКА М.В.

\title{
ПРИПИНЕННЯ ТРУДОВИХ ВІДНОСИН ТА СУМІЖНІ КАТЕГОРІЇ: ПОРІВНЯЛЬНО-ПРАВОВИЙ АНАЛІЗ
}

У статті досліджено правову категорію «припинення трудових відносин», виділено та проаналізовано категорії, суміжні до цього поняття, - «припинення трудового договору», «розірвання трудового договору» та «звільнення працівників». Визначено характерні особливості поняття «припинення трудових відносин» та кожної з наведених суміжних категорій. Виокремлено критерії, за якими здійснено аналіз поняття припинення трудового договору та суміжних категорій. За результатами дослідження встановлено спільне та відмінне у категоріях, суміжних 3 поняттям припинення трудового договору. Наголошено, що за критерієм волі та волевиявлення припинення трудового договору класифікують на припинення трудового договору за угодою сторін, розірвання трудового договору за ініціативою працівника, розірвання трудового договору за ініціативою роботодавця, розірвання трудового договору за ініціативою третіх осіб та припинення трудового договору внаслідок подій. Визначено, що поняття «припинення трудових відносин» та «звільнення працівника» характеризуються наступними спільними та відмінними рисами: наслідком і припинення трудових відносин, і звільнення працівників $\epsilon$ розірвання будь-яких трудових зв'язків між роботодавцем і працівником; i припинення трудових відносин, і звільнення працівника потребують додержання передбаченої законом процедури та строків; припинення трудових правовідносин $\epsilon$ найширшою категорією, однією із підстав для якої $є$ звільнення; звільнення працівника є одностороннім волевиявленням, а припинення трудових відносин - багатостороннім; звільнення не може відбутись за мовчазної згоди сторін трудового договору. Зроблено висновок, що припинення трудових правовідносин $є$ найбільш загальною категорією, яка, зокрема, за ознакою ініціативності суб'єкта включає усі інші категорії. При цьому припинення трудового договору можливе за ініціативи не лише працівника, роботодавця, третіх осіб, але і у зв'язку із подіями. Водночас звільнення $є$ категорією, яка вимагає наявності вольових дій суб'єктів правовідносин. Різниця останньої категорії порівняно із розірванням трудового договору полягає у тому, що звільнення може відбутися на підставі взаємних двосторонніх дій, тоді як розірвання договору є одностороннім правочином.

Ключові слова: трудові відносини, трудовий договір, припинення трудового договору, розірвання трудового договору, звільнення, ініціатива працівника, ініціатива роботодавия.

The article examines the legal category of "termination of employment", highlights and analyzes the categories related to this concept - termination of employment contract, cancellation of an employment contract, dismissal and layoffs of employees. The characteristic features of the concept of termination of employment and each of the related categories are revealed. The criteria according to which the analysis of the concept of termination of employment contract and related categories is carried out are singled out. The study identified common and distinctive features of categories related to the concept of termination of employment. It is emphasized that according to the criterion of will and expression of will, termination of employment is classified as termination of employment by agreement of the parties, termination of employment at the initiative of the employee, termination of employment at the initiative of the employer, termination of employment at the initiative of third parties. It is determined that "termination of em-

(C) КОМАРНИЦЬКА М.В. - аспірант кафедри трудового права та права соціального забезпечення юридичного факультету (Київський національний університет імені Тараса Шевченка) 
ployment" and "dismissal" are characterized by the following common and distinctive features: the consequence of termination of employment, and dismissal is the severance of any employment relationship between employer and employee; both termination of employment and dismissal of the employee require compliance with the procedure and deadlines prescribed by law; termination of employment is the broadest category, one of the grounds for which is dismissal; dismissal of an employee is a unilateral expression of will, and termination of employment is multilateral; dismissal cannot take place with the tacit consent of the parties to the employment contract. It is concluded that the termination of employment is the most common category, which in particular on the basis of the initiative of the subject includes all other categories. In this case, the termination of the employment contract is possible not only at the initiative of the employee, employer, third parties, but also in connection with the events. At the same time, dismissal is a category that requires the presence of willful actions of the subjects of legal relations. The difference of the latter category in comparison with the termination of the employment contract is that the dismissal can be based on mutual bilateral actions, while the termination of the contract is a unilateral transaction.

Key words: employment relations, employment contract, termination of employment contract, cancellation of an employment contract, dismissal, layoffs of employees, employee initiative, employer initiative.

Вступ. Норми, які регулюють припинення трудового договору, займають важливе місце серед норм, які регламентують трудові відносини. Існують різноманітні підходи вчених до визначення поняття «припинення трудових відносин», а також численні суміжні поняття, щодо яких також немає одностайності серед науковців. Відсутність у чинному законодавстві України про працю єдиних підходів до термінології, яка використовується у разі припинення трудових правовідносин, створює додаткові підстави для дискусії внаслідок різних поглядів вчених на визначення понять, їх співвідношення та виділення загальних та відмінних рис.

3 огляду на значущість в інституті трудового договору норм, які врегульовують припинення трудових правовідносин, як для теорії трудового права, так і для практики застосування цих норм науково обгрунтованою та актуальною $є$ потреба у детальному дослідженні поняття «припинення трудових відносин», виокремленні суміжних з ним правових категорій та здійсненні порівняльно-правового аналізу поняття «припинення трудових відносин» та цих суміжних категорій. Слід зауважити, що виділення понять, суміжних до поняття «припинення трудових відносин», неможливе без повнішого розкриття сутності самого поняття «припинення трудових відносин», висвітлення його характерних особливостей через призму дослідження поглядів вчених на це поняття та їх критичної оцінки.

Аналіз понять, суміжних до поняття «припинення трудових відносин», а також визначення критеріїв, за якими можливо здійснити порівняльно-правовий аналіз цього поняття та суміжних категорій, має на меті актуалізувати питання необхідності усунення численних суперечностей та неузгодженостей законодавства про працю у сфері припинення трудових відносин, приведення у відповідність термінології. Таким чином, це дослідження спрямоване на вирішення наявних термінологічних суперечностей та покликане сприяти усуненню проблем під час розуміння, застосування та тлумачення правових норм, які регулюють припинення трудових відносин.

Постановка завдання. Завданнями дослідження є: 1) різностороннє дослідження поняття «припинення трудових відносин», виділення та вивчення суміжних понять; 2) формулювання критеріїв, за якими можливо здійснити порівняльно-правовий аналіз поняття «припинення трудових відносин» та суміжних правових категорій, 3) виокремлення спільних та відмінних рис категорії «припинення трудових правовідносин» та суміжних із нею категорій.

Стан дослідження. Припинення трудових правовідносин та суміжні із ним категорії були предметом наукових досліджень таких учених, як Е.В. Бабенко, А.Ю. Бабаскін, Ю.В. Баранюк, Н.Б. Болотіна, В.С. Венедіктов, С.М. Глазько, Ю.А. Джепа, С.В. Дріжчана, Ю.П. Дмитренко, В.В. Жернаков, В.М. Зеленський, В.В. Єрьоменко, М.І. Іншин, В.Л. Костюк, К. Ю. Мельник, В.П. Мельник, В.О. Процевський, О.В. Прудивус, С.В. Селезень, Я.В. Сімутіна, Ф. А. Цесарський, Г.І. Чанишева.

Результати дослідження. У науковій літературі досить часто вчені пов'язують припинення трудових правовідносин із припиненням чи розірванням трудового договору. Це $\epsilon$ помилкою та ніяким чином не може бути обгрунтовано. Залежно від того, як сприймається в науці спів- 
відношення припинення трудових правовідносин та припинення трудового договору, визначається момент припинення трудових правовідносин, що своєю чергою впливає на здійснення та захист прав та інтересів працівників [1, с. 90]. Фактично від правильного розуміння змісту поняття «припинення трудових правовідносин» та суміжних понять залежить якість захисту прав суб'єктів трудових правовідносин у разі їх припинення. Водночас відзначимо, що припинення трудових відносин як самостійне поняття не є широко досліджуваним у наукових колах, оскільки вченими здебільшого аналізуються саме суміжні поняття, такі як «припинення та розірвання трудового договору», «звільнення працівника».

На подібній правовій проблемі, зокрема в межах правового регулювання, зосередила увагу Я.В. Сімутіна, яка відзначила, що у чинному законодавстві про працю для позначення припинення трудових правовідносин вживаються різні за своїм змістом поняття: «припинення трудового договору», «розірвання» трудового договору, «звільнення працівника», «вивільнення працівника» [2, с. 161]. Очевидним є той факт, що питання недостатності теоретичних розробок розуміння припинення трудових відносин та ототожнення ряду суміжних понять пов'язане саме iз відсутністю чіткого правового регулювання в цій сфері.

У межах нашого дослідження вважаємо за необхідне перш за все висвітлити підходи вчених до розуміння дефініцій явищ, які є суміжними до припинення трудових відносин, що дозволить встановити перелік взаємопов'язаних із припиненням трудових відносин категорій, а також чітко диференціювати їх за сформованими критеріями. Саме зміст дефініцій дозволить сформувати перелік суміжних до припинення трудових правовідносин категорій. При цьому вважаємо, що обрання суміжних категорій в межах дослідження повинно здійснюватися за їх наслідком завершенням здійснення працівником роботи, дії взаємних прав та обов'язків, тобто фактично припиненням трудових правовідносин.

Аналіз праць учених показав, що найбільш поширеними серед напрямів наукових досліджень є питання таких правових категорій, наслідком яких є припинення трудових відносин, як-от: «припинення трудового договору», «розірвання трудового договору» та «звільнення працівника».

Щодо припинення трудового договору, то М.I. Іншин відзначає, що це припинення дії трудового договору та трудових правовідносин між роботодавцем та працівником [3, с. 225]. Фактично основою умовою, яка протиставляється загальному припиненню трудових відносин у зв'язку із припиненням трудового договору, є дія договору. Тобто в цьому разі факт припинення дії договору є підставою для припинення трудових відносин загалом.

На думку Н.Б. Болотіної, припинення трудового договору є найбільш широким за обсягом та охоплює всі випадки закінчення дії трудового договору, у тому числі за угодою сторін, унаслідок вибуття зі складу підприємства тощо [4, с. 281]. Таким чином, вчена також вказує на необхідність припинення дії договору як основоположної ознаки припинення трудових правовідносин. При цьому небезпідставно відмічено, що за своїм обсягом відповідна правова категорія включає усі підстави припинення дії, що, безумовно, вказує на досить широкий зміст цього поняття.

К.Ю. Мельник також схиляється до вищенаведеного обсягу поняття «припинення трудового договору», відзначаючи, що під ним слід розуміти закінчення дії договору за всіма підставами, передбаченими трудовим законодавством [5, с. 182]. За відповідного тлумачення обсяг змісту дефініції «припинення трудового договору» наближається до припинення трудових відносин загалом.

В.С. Венедіктов під припиненням трудового договору пропонує розуміти родове поняття, яке об'єднує всі підстави розірвання трудових зв'язків, як за ініціативою працівника, власника чи уповноваженого ним органу, третіх осіб, так і у зв'язку з вибуттям працівника зі спискового складу підприємства або у зв'язку з його смертю [6, с. 106]. Тобто вченим також підтримується позиція про широкий обсяг змісту цього поняття, при цьому деталізовано суб'єктів, які можуть бути ініціаторами припинення дії трудового договору, яке, як випливає із відзначеного ученим переліку, фактично охоплює усіх суб'єктів трудових правовідносин.

Щодо поняття «звільнення», то В.В. Жернаков наголошує, що воно вживається стосовно працівника та за змістом є синонімом до терміну «припинення трудового договору» [7, с. 208]. Ми не можемо погодитись із такою позицією, оскільки звільнення, на нашу думку, є більш вузьким за своїм змістом поняттям.

Подібної позиції дотримується К.Ю. Мельник, відзначаючи, що термін «звільнення 3 роботи» $є$ за змістом синонімом терміну «припинення трудового договору», за такими винятками, як смерть працівника, визнання його безвісно відсутнім чи оголошення померлим, а також 
смерть роботодавця - фізичної особи, визнання його безвісно відсутнім або оголошення померлим [5, с. 182]. Тобто поняття «припинення трудового договору» і «звільнення» $є$ подібними поняттями, що дозволяє зробити висновок про їх суттєву тотожність та синонімічність, однак у зв'язку із наявністю винятків, за яких дефініція звільнення не застосовується, логічним є висновок про різний обсяг цих понять.

Дещо іншої думки притримується А.Ю. Бабаскін, Ю.В. Баранюк і С.В. Дріжчана, які вважають, що звільнення з роботи в усіх випадках є тотожним із терміном «припинення трудового договору», йому притаманна сама процедура технічного оформлення припинення трудових правовідносин [8, с. 208]. У зв'язку із наявністю вищенаведених підстав для припинення трудового договору ми не можемо погодитись із абсолютною тотожністю обсягів розуміння припинення трудового договору та звільнення. Водночас притаманність звільненню процедури технічного оформлення припинення трудових відносин $є$ досить цікавою з наукового погляду. Однак ми не поділяємо подібну позицію з огляду на те, що припинення трудового договору $є$ цілісним процесом, який, зокрема, передбачає документальне оформлення відповідних дій, що ставить під сумнів наведений критерій для диференціації понять.

Наступною суміжною категорією $є$ розірвання трудового договору, яке, на думку Ю.П. Дмитренко, є вольовим ініціативним припиненням договору у визначеному законодавством порядку однією із сторін трудових відносин чи третьою особою. Ініціаторами можуть виступати: працівник, власник або уповноважений ним орган (роботодавець), треті особи (суд, профспілки, військкомат тощо) [5, с. 228]. Тобто критеріями, за якими розірвання договору може бути відокремлено від інших категорій в межах припинення трудових відносин, $є$ вольовий характер відповідних дій, а також наявність певного суб'єкту, який виступає з ініціативою щодо відповідного розірвання.

На вольовому характері розірвання трудового договору наголошує і К.Ю. Мельник, називаючи його припиненням за ініціативою працівника, або роботодавця, або осіб, що мають право вимагати його припинення [9, с. 182]. Фактично саме за активністю дій, що виявляється у вольовій діяльності належних суб'єктів, розірвання трудового договору може бути диференційоване від інших суміжних із припиненням трудових відносин категорій.

Враховуючи наведене вище, з метою диференціації поняття припинення трудових правовідносин із суміжними категоріями та виокремлення їх спільних та відмінних рис пропонуємо використовувати такі критерії:

1) ініціативність сторони правовідносин, що характеризується наявністю можливості своїми вольовими діями припиняти трудові правовідносини;

2) темпоральні межі припинення трудових правовідносин, тобто строки, в межах яких трудові правовідносини припиняються у разі застосування сторонами однієї з досліджуваних категорій;

3) наявність гарантій у разі припинення трудових відносин (наприклад, наявність відшкодування з боку працівника або роботодавця);

4) нормативно-правове регулювання процедури припинення трудових правовідносин.

Перш за все слід відзначити, що за своєю суттю припинення трудових правовідносин i припинення трудового договору - це дві взаємозв'язані, але не однакові за своїм змістом правові категорії. Зміст трудових правовідносин становлять трудові права і обов'язки їх суб'єктів, а змістом трудового договору є його умови. Отже, «припинення трудового договору» та «припинення трудових правовідносин» - це дві правові категорії, які співвідносяться як частина та ціле. Припинення трудового договору, по суті, можна вважати однією 3 підстав припинення трудових відносин. При цьому слід вирізняти підстави та умови припинення трудових правовідносин. Умовами припинення трудових правовідносин $є$ сукупність таких обставин, за наявності яких трудові правовідносини можуть бути припинені [10, с. 197]. Фактично припинення трудових правовідносин $є$ найширшою категорію, яка включатиме у себе ознаки всіх інших досліджуваних категорій. Тому доцільним, на нашу думку, $є$ проведення диференціації суміжних категорій між собою за критеріями, наведеними в переліку. Категорія «припинення трудових правовідносин» фактично буде охоплювати ознаки, притаманні усім суміжним категоріям.

Аналізуючи розглядувані категорії крізь призму ініціативності сторони правовідносин, відзначимо, що Г.І. Чанишева і Н.Б. Болотіна усі підстави припинення трудового договору класифікують залежно від двох критеріїв: 1) виду юридичного факту, що є причиною припинення (діяльність чи бездіяльність) та 2) волевиявлення яких саме суб'єктів потягло припинення трудового договору [11, с. 232]. Саме в розумінні можливості проявлення свого волевиявлення в цілях припинення трудових правовідносин полягає досліджуваний критерій диференціації. 
Своєю чергою Т.Ю. Коршунова поділяє всі підстави припинення трудового договору на три великі групи. До першої належать підстави, пов'язані з бажанням обох сторін або однієї зі сторін трудового договору припинити його дію. Цю групу складають підстави для розірвання трудового договору за згодою сторін, з ініціативи роботодавця, з ініціативи працівника, а також переведення працівника за його проханням або з його згоди до іншого роботодавця або перехід на виборну посаду. До другої групи належать підстави, пов'язані з неможливістю продовження трудових відносин з обставин, що не залежать від волі сторін, а також у зв'язку із закінченням строку трудового договору або порушенням встановлених правил укладення трудового договору. Третю групу становлять підстави, пов'язані з відмовою працівника з різних причин від продовження трудових відносин з роботодавцем [12, с. 35]. Ми не можемо цілком погодитись із відповідною класифікацію, оскільки перша та третя групи фактично є проявом волі сторін.

Розглядаючи можливих ініціаторів припинення трудових відносин в межах досліджуваних категорій, С.М. Глазько визначає розірвання трудового договору як припинення трудових правовідносин за волевиявленням сторін трудового договору або за вимогою інших громадських організацій чи державних органів [13, с. 18]. Подібну позицію підтримують і інші вчені, вказуючи, що термін «розірвання трудового договору» означає його припинення за одностороннім волевиявленням роботодавця, працівника, а також на вимогу профспілкового органу [14, с. 507]. Таким чином, доходимо висновку, що ініціатором розірвання трудового договору може бути одна сторона - працівник, роботодавець або третя особа.

За критерієм волі та волевиявлення припинення трудового договору класифікують на припинення трудового договору за угодою сторін, розірвання трудового договору за ініціативою працівника, розірвання трудового договору за ініціативою роботодавця, розірвання трудового договору за ініціативою третіх осіб та припинення трудового договору внаслідок подій $[15, \mathrm{c}$. 128]. Отже, припинення трудового договору включає його розірвання однією із сторін, а також припинення за взаємною згодою сторін або внаслідок подій.

При цьому В.В. Срьоменко вказує, що за винятком випадків смерті працівника припинення трудового договору означає одночасне звільнення працівника. Розірвання трудового договоpy, на їх думку, означає його припинення одностороннім волевиявленням [16, с. 211]. Цікавим 3 наукового погляду $є$ ототожнення звільнення та припинення трудового договору, за винятком частини припинення договору внаслідок смерті. Разом з тим ми не можемо погодитись із єдиною подією, яка є винятком згідно з зазначеною позицією.

Так, до підстав припинення трудового договору деякі учені відносять: а) смерть працівника; б) смерть роботодавця - фізичної особи; в) порушення правил прийняття на роботу; г) настання надзвичайних обставин; д) визнання працівника повністю непрацездатним згідно з медичним висновком; є) поновлення на роботі працівника, який раніше виконував цю роботу; ж) направлення працівника за постановою суду до лікувально-трудового профілакторію [17, с. 291]. Таким чином, очевидним $\epsilon$ необхідність широкого розуміння підстав для припинення трудового договору, які не можуть обмежуватись єдиним елементом - смертю працівника.

Також слід згадати позицію О.І. Процевського, який стверджує, що звільнення являє собою припинення трудового договору внаслідок двостороннього волевиявлення, наприклад, звільнення за угодою чи з ініціативи сторін. Поняття «розірвання трудового договору» застосовується у разі припинення трудового договору з ініціативи однієї із сторін чи профспілкового органу [18, с.108-109]. Отже, поняття «звільнення» $є$ більш ширшим за поняття «розірвання договору», однак $€$ вужчим, ніж категорія «припинення трудового договору», оскільки включає лише вольові підстави припинення відносин та не грунтується на подіях.

Розглядаючи досліджувані категорії крізь призму темпоральних меж припинення трудових відносин, відзначимо, що усі суміжні із припиненням трудових правовідносин категорії мають різні строки досягнення результату у вигляді припинення відносин. При цьому для формування розуміння про встановлені строки доцільно звернутись до законодавства, яке їх регулює.

Так, наприклад, згідно зі статтею 38 КЗпП працівник має право розірвати трудовий договір, укладений на невизначений строк, попередивши про це власника або уповноважений ним орган письмово за два тижні. При цьому за наявності окремих підстав цей строк може бути зменшено [19]. Таким чином, строк до припинення трудових правовідносин обмежено двома календарними тижнями у разі розірвання працівником безстрокового трудового договору.

Статтею 43 КЗПП передбачено, що у випадках, визначених трудовим законодавством, виборний орган профспілки, членом якої $є$ працівник, повинен розглянути подання роботодавця про розірвання трудового договору протягом 15 днів. При цьому повідомлення про прийняте рі- 
шення за результатом розгляду подання повинне бути надане в письмовій формі протягом трьох днів з моменту прийняття рішення [19]. Фактично у випадках розірвання трудового договору за ініціативою роботодавця, в разі необхідності отримання згоди профспілкової організації, строк припинення трудових правовідносин обмежено 18 днями.

При цьому відзначимо, що інші випадки припинення трудових відносин не передбачають необхідності дотримання окремих строків, що вказує на відсутність правових вимог у цій частині. Таким чином, за темпоральними межами припинення трудових правовідносин категорії «припинення трудових відносин», «припинення трудового договору», «звільнення та розірвання трудового договору» мають загалом лише спільні ознаки, за винятком розірвання трудового договору за ініціативою працівника чи роботодавця, які потребують дотримання ініціатором встановлених законодавством строків до моменту фактичного настання результату - припинення трудових правовідносин.

Питання наявності гарантій внаслідок припинення трудових правовідносин слід також розглядати залежно від суб'єкту, який був ініціатором припинення трудових правовідносин.

Слід відзначити, що трудовим законодавством України передбачено низку гарантій захисту прав працівників у разі, якщо роботодавець розриває трудовий договір зі своєї ініціативи. Зокрема, забороняється звільнення за підставами, передбаченими пунктами 1, 2 і 6 ст. 40 КЗпП України, якщо відсутня можливість перевести працівника на іншу роботу, на яку він дає згоду. Також роботодавцю не дозволяється звільняти працівників під час їх тимчасової непрацездатності, за винятком звільнення згідно з частиною 5 ст. 40 КЗпП України. Працівники, які перебувають у відпустці, можуть бути звільнені лише у разі повної ліквідації юридичної особи - роботодавця. Важливою гарантією працівника $є$ обов'язок роботодавця виплатити вихідну допомогу, розмір якої не може біти меншим за середній заробіток, у разі, якщо звільнення здійснюється за підставами, передбаченими п. 6 ст. 36, п.п. 1, 2, 6 ст. 40 КЗпП України. Вихідна допомога в розмірі двох мінімальних заробітних плат виплачується працівнику, якщо він вступає на військову службу або наплавляється на альтернативну. Якщо ж роботодавець порушує законодавство про працю чи умови колективного договору, то розмір вихідної допомоги визначається колективним договором і не може бути меншим за трикратний середній місячний заробіток. Розрахунок 3 працівником повинен здійснюватися в день звільнення, разом з видачею трудової книжки. При цьому, якщо звільнення здійснювалось за ініціативи роботодавця, то він повинен видати копію наказу про звільнення.

Таким чином, у процесі аналізу категорії припинення трудових відносин та суміжних категорій нами встановлено таке:

1) серед суміжних категорій до категорії «припинення трудових відносин» нами віднесено «припинення трудового договору», «розірвання трудового договору» та «звільнення працівника»;

2) встановлено, що кожні із цих категорій характеризуються як спільними, так і відмінними рисами. До спільних рис належать такі:

- i припинення трудових відносин, і припинення трудового договору передбачають, що із моменту припинення працівник та роботодавець більше не перебувають у трудових правовідносинах між собою;

- і припинення трудових відносин, і припинення трудового договору можуть ініціюватись однією із сторін, за взаємною згодою сторін або внаслідок настання певних подій;

- i припинення трудових відносин, і припинення трудового договору потребують додержання передбаченої законом процедури та строків.

Відмінними ж рисами є:

- термін «припинення трудового договору» $є$ таким, який найчастіше вживається науковцями та законодавцем в Кодексі законів про працю України [19], а припинення трудових відносин вживається значно рідше;

- незважаючи на очевидний зв'язок двох категорій, вони не є однаковими за своїм змістом, адже зміст трудових правовідносин становлять трудові права і обов'язки їх суб'єктів, а змістом трудового договору є його умови;

- припинення трудового договору та припинення трудових правовідносин співвідносяться як частина та ціле, адже припинення трудового договору, по суті, $є$ однією з підстав припинення трудових відносин;

4) «припинення трудових відносин» та «розірвання трудового договору» характеризуються такими спільними рисами:

- наслідком і припинення трудових відносин, і розірвання трудового договору є розірвання будь-яких трудових зв'язків між роботодавцем і працівником; 
- i припинення трудових відносин, і припинення трудового договору потребують додержання передбаченої законом процедури та строків);

Серед відмінних рис нами відзначено такі:

- термін «розірвання трудового договору» вживається законодавцем в Кодексі законів про працю України [19], а «припинення трудових відносин» ні;

- поняття «розірвання трудового договору», яке за своєю сутністю означає припинення трудового договору одностороннім волевиявленням і при цьому немає значення з чиєї ініціативи розірвання відбувається - працівника, роботодавця чи третьої особи, а ініціатором припинення трудових відносин може бути одна із сторін, припинення може відбуватись за взаємною згодою сторін або внаслідок настання певних подій;

- припинення трудових правовідносин $є$ ширшою категорію, яка включає у тому числі й розірвання трудового договору як одну із підстав;

- строк до припинення трудових правовідносин обмежено двома календарними тижнями у разі розірвання працівником безстрокового трудового договору, а у разі розірвання трудового договору за ініціативою роботодавця, в разі необхідності отримання згоди профспілкової організації, строк припинення трудових правовідносин обмежено 18 днями;

- у разі розірвання трудового договору з ініціативи роботодавця працівникам надаються додаткові гарантії, а у разі припинення трудових відносин за іншими підставами ні;

5) «припинення трудових відносин» та «звільнення працівника» характеризуються наступними спільними рисами:

- наслідком і припинення трудових відносин, і звільнення працівників $є$ розірвання будьяких трудових зв'язків між роботодавцем і працівником;

- і припинення трудових відносин, і звільнення працівника потребують додержання передбаченої законом процедури та строків;

Відмінні риси:

- припинення трудових правовідносин $є$ найширшою категорією, однією із підстав для якої є звільнення;

- звільнення працівника є одностороннім волевиявленням, а припинення трудових відносин - багатостороннім;

- звільнення не може відбутись за мовчазної згоди сторін трудового договору.

Висновки. Проведений нами аналіз дозволив виявити такі суміжні припиненню трудових правовідносин категорії, як припинення трудового договору, розірвання трудового договору та звільнення. Очевидно, що сама ознака суміжності наведених категорій дає підстави вважати, що вони мають спільні риси, однак у зв'язку із відсутністю їх тотожності важливим є формування рис, за якими згадані категорії можливо диференціювати.

Аналіз за сформованими критеріями дозволив зробити висновок, що припинення трудових правовідносин $є$ найбільш загальною категорією, яка, зокрема, за ознакою ініціативності суб'єкта включає усі інші категорії. При цьому припинення трудового договору можливе за ініціативи не лише працівника, роботодавця, третіх осіб, але і у зв'язку із подіями. Водночас звільнення $\epsilon$ категорією, яка вимагає наявності вольових дій суб'єктів правовідносин. Різниця останньої категорії порівняно із розірванням трудового договору полягає у тому, що звільнення може відбутися на підставі взаємних двосторонніх дій, тоді як розірвання договору є одностороннім правочином.

Дослідження суміжних із припиненням трудових правовідносин категорій за критеріями темпоральних меж та наявності гарантій у разі припинення відносин привело нас до висновку, що відповідні ознаки є обов'язковими рисами лише частини досліджуваних категорій, зокрема в частині розірвання трудового договору.

Водночас наявність нормативно-правового регулювання та його зміст і закріплення в конкретних актах $є$ спільною для усіх досліджуваних категорій рисою, що може виокремлювати лише різні види припинення трудових правовідносин щодо окремих видів суб'єктів, праця яких має високу соціальну цінність.

\section{Список використаних джерел:}

1. Джепа Ю.А. Особливості гарантій захисту прав суб'єктів трудового права при припиненні трудових правовідносин. Форум права. 2008. № 2. С. 90-94.

2. Сімутіна Я.В. Правове регулювання припинення трудового договору за угодою сторін та з ініціативи працівника: окремі проблеми. Держава і право. Юридичні і політичні науки. 2014. Вип. 65. С. 159-167. 
3. Трудове право України [текст] підручник. За загальною редакцією М.І. Іншина, В.Л. Костюка, В.П. Мельника. Вид. 2-ге, перероб. і доп. Київ : Центр учбової літератури, 2016. 472 с.

4. Болотіна Н.Б. Трудове право України : [підручник]. Київ : Вікар, 2003. 725 с.

5. Мельник К.Ю. Трудове право України : підручник. Харків : Діса плюс, 2014. 480 с.

6. Венедиктов В.С. Трудовое право Украины. Харків : Консум, 2004. 304 с.

7. Трудове право : [підручник для студ. юрид. спец. вищ. навч. закл.]. [В.В. Жернаков, С.М. Прилипко, О.М. Ярошенко та ін.] ; за ред. В.В. Жернакова. Харків : Право, 2012. 496 с

8. Трудове право України. Академічний курс : [підручник]. [А.Ю. Бабаскін, Ю.В. Баранюк, С.В. Дріжчана та ін.] ; за заг. ред. Н.М. Хуторян. Київ : А.С.К., 2004. 608 с.

9. Трудове право України : підручник. Ю.П. Дмитренко. Київ : ЮрінкомІнтер, 2009. 624 с.

10. Шишлюк В.Р., Краснов С.В. До питання співвідношення понять «припинення трудового договору» та «припинення трудових відносин». VII Міжнар. наук. конф. студ., аспір. та молод. вчених «Правове забезпечення соціальної сфери». 2016. С. 197-199.

11. Теорія держави і права : навчальний посібник. За заг. ред. С.Л. Лисенкова, В.В. Копейчикова. Київ, 2002.

12. Коршунова Т.Ю. Трудовой договор в современных условиях (к вопросу о найме труда). Государство и право. 1994. № 2. С. 30-41.

13. Глазько С.М. Правове регулювання припинення трудового договору: теоретичний аспект : автореф. дис. ... канд. юрид. наук : спец. 12.00.05 «Трудове право; право соціального забезпечення». С.М. Глазько ; Нац. ун-т внутр. справ. Харків, 2005. 20 с.

14. Цесарський Ф.А. Підстави припинення трудового договору як проблемне питання науки трудового права. Актуальні проблеми держави і права. 2011. Вип. 61. С. 505-511.

15. Єрьоменко В.В. Підстави виникнення, зміни і припинення трудових правовідносин. Актуальні проблеми розвитку законодавства про працю та соціальне забезпечення: Тези доповідей і наукових повідомлень учасників Міжнародної науково-практичної конференції, (Харків, 22-23 квітня 2009 р.). за ред. В.В. Жернакова. Харків : Національна юридична академія України імені Ярослава Мудрого, 2009. С. 124-128.

16. Ролкер Р. Английская судебная система. Москва : Юрид. лит., 1980. 248c.

17. Глазько С.М. Класифікація підстав припинення трудового договору з працівниками. Вісник Харківського національного університету внутрішніх справ. 2005. Вип. 29. С. 286-292.

18. Процевський В.О. Трудове право України : навчальний посібник. Харків : ХНПУ ім. Г.С. Сковороди, 2006. 264 с.

19. Кодекс законів про працю України: Закон України від 10.12.1971 р. № 322-VIII. Відомості Верховної Ради УРСР. 1971. Додаток до № 50. Ст. 375. URL: http://zakon5.rada.gov.ua/laws/ show/322-08 (дата звернення: 09.10.2019). 